\title{
RELATIONSHIPS BETWEEN BROWSING DAMAGE AND THE SPECIES DOMINANCE BY THE HIGHLY FOOD-ATTRACTIVE AND LESS FOOD-ATTRACTIVE TREES
}

\author{
P. Čermák, P. Beranová, J. Orálková, P. Horsák, J. Plšek \\ Received: September 6, 2010
}

\begin{abstract}
ČERMÁK, P., BERANOVÁ, P., ORÁLKOVÁ, J., HORSÁK, P., PLŠEK, J.: Relationships between browsing damage and the species dominance by the highly food-attractive and less food-attractive trees. Acta univ. agric. et silvic. Mendel. Brun., 2011, LIX, No. 1, pp. 29-36

The paper analyses data on the browsing damage to Acer pseudoplatanus, Carpinus betulus, Fraxinus excelsior, Quercus spp., Tilia cordata and Fagus sylvatica. Field research was carried out in the period 20072010 and analysed data came from 33 transects at 10 localities with the various abundance of game in the CR (everywhere Capreolus capreolus, on several plots also Cervus elaphus, Ovis musimon or Dama dama). Trees were monitored up to a height of $150 \mathrm{~cm}$ in natural regeneration under stands and in plantations and the occurrence was noted of new browsing damage. Differences between the percentage of damaged individuals of the given species of a food-attractive species (A.p., C. b., F. e.) and the percentage of damaged individuals of all tree species on a transect as well as the proportion of these parameters correlate negatively with the given species dominance and thus, they appear to be suitable parameters for the analysis of relationships between the damage intensity and dominance. The higher the percentage proportions of highly food-attractive species and the lower the percentage of less-attractive species, the lower the relative intensity of damage to highly food-attractive species. At the same time, the higher the percentage proportion of highly food-attractive species and the lower the percentage of less-attractive species then the lower a difference between damage to less food-attractive species and all species.
\end{abstract}

browsing, dominance, highly food-attractive species, less food-attractive species, correlation

The attractiveness of tree species for ruminant consumers is highly species-specific, however, damage to particular tree species markedly differs at various localities, namely in absolute values and in relation to other species. Generally, the species structure of advance regeneration and the species rareness are the most mentioned factors affecting the preference of a species by browsing animals. That is, tree species are usually more intensively searched if they are in combination with less attractive species and relative damage is often in relation to the species relative abundance or its dominance. In some cases, the damage increases with the relative proportion of a species, in other cases increases with the decreas- ing proportion of these species in advance growth both polarities of relationships being interpretable (STROLE, ANDERSON, 1999; ČERMÁK et al., 2009). In addition to the actual species attractiveness, e.g. differences in the rate of stress caused by browsing animals, their applied food strategy, intensity of tree competition and the species composition of advance growth can represent a substantial role. Relationships between dominance and damage are documented and commented in literature, however, often only for one species or a particular stand mixture (e.g. PADAIGA, 1986; DANELL et al., 1991; ČERMÁK, 1998). Relationships of four food-attractive species Acer pseudoplatanus, Acer platanoides, Acer 
campestre, Fraxinus excelsior and Sorbus aucuparia and one less food-attractive eudominant species Fagus sylvatica including the suitability of using particular possible parameters are discussed in a paper of ČERMÁK et al. (2009).

In 2007-2010, we carried out monitoring the browsing damage to trees on several areas with the similar composition of tree species. The primary objective of these surveys was to determine the condition of natural regeneration and plantings as well as their damage. Procedures including rather large variability in the area of plots were, therefore, adapted to this aim. Nevertheless, problems of relationships between the intensity of damage and dominance of a species in advance regeneration or plantations were one of important questions dealt with by our research team. Therefore, we carried out an analysis of relationships between the intensity of damage and dominance according to a procedure already used for an extensive series of plots from 2005-2007 (ČERMÁK et al., 2009) for the most frequent and abundant broadleaved species (Fagus sylvatica, Acer pseudoplatanus, Quercus spp. - Quercus petraea and Quercus robur, Carpinus betulus, Fraxinus excelsior and Tilia cordata). Our aim was (in addition to checking relationships determined in a previous study) to analyse relationships between the damage intensity and dominance at species, the rate of attractiveness of which is not unambiguous. For oaks (Quercus spp.), it is possible to find different data on their attractiveness in literature. For example, HOLIŠOVÁ et al. (1986), GARTNER (1996), HEROLDOVÁ (1997) or KULLBERG, BERGSTRÖM (2001) mention species of oak to be frequently looked out and highly damaged particularly by roe deer (Capreolus capreolus). During the survey of damage to trees at several Moravian localities (ČERMÁK, 2000), oak damage was, however, notably lower than damage to most attractive species, viz. maple, rowan or ash at the majority of plots. Lime Tilia cordata is frequently moderately or little damaged by browsing and, therefore, it is largely considered to be a less food-attractive species (HEROLDOVÁ, 1997; KULLBERG, BERGSTRÖM, 2001). Also for this species, however, it is possible to find studies where its damage exceeds damage to maple or ash (KAY, 1993).

\section{MATERIAL AND METHODS}

Browsing damage was monitored on transects $3 \mathrm{~m}$ wide and 10 to $45 \mathrm{~m}$ long and on plots of a size from 9 to $120 \mathrm{~m}^{2}$ (area of transects and plots was assessed in agreement with tree density). Transects were established in stands where evidence of natural regeneration was already apparent. Browsing was evaluated in all species up to a height of $150 \mathrm{~cm}$. Current damage was assessed, i.e. damage coming from the past winter and actual growing season. Trees with damaged terminal shoots or heavy damage to lateral shoots (more than $20 \%$ shoots damaged) were evaluated as damaged. In 2007-2010, this monitoring was realized at more than 80 transects of 15 localities in the CR. Out of these plots, 33 transects at 10 localities were selected and species mentioned above were included there. Basic characteristics of localities are given in Tab. I. The plots characterize the wide range of natural conditions from the $2^{\text {nd }}$ to the $5^{\text {th }}$ forest vegetation zone. In advance growth, following species mainly occurred: Acer pseudoplatanus, Carpinus betulus, Fagus sylvatica, Fraxinus excelsior, Quercus spp., Tilia cordata (see Table II). Other species occurred in small proportion < 10\% (20 transects); in the part of plots, there were the very broad spectrum of other species (6 transects) and in remaining plots, Picea abies or Abies alba (7 transects) showed significant proportion. As for ungulates, Capreolus capreolus occurred in all areas, Cervus elaphus at 3 localities, Dama dama at 4 localities and Ovis musimon at 3 localities. The converted abundance of game (according

I: Basic characteristics of monitored localities

\begin{tabular}{|c|c|c|c|c|c|c|c|c|}
\hline \multirow[b]{2}{*}{ Locality } & \multirow{2}{*}{$\begin{array}{c}\text { Number } \\
\text { of transects }\end{array}$} & \multirow{2}{*}{$\begin{array}{c}\text { Total } \\
\text { area } \mathbf{m}^{2}\end{array}$} & \multirow{2}{*}{$\begin{array}{c}\text { Year of } \\
\text { monitoring }\end{array}$} & \multicolumn{5}{|c|}{ Number of game / 1000 ha } \\
\hline & & & & $\begin{array}{l}\text { Capreolus } \\
\text { capreolus }\end{array}$ & $\begin{array}{c}\text { Cervus } \\
\text { elaphus }\end{array}$ & $\begin{array}{l}\text { Dama } \\
\text { dama }\end{array}$ & $\begin{array}{c}\text { Ovis } \\
\text { musimon }\end{array}$ & Ungulate* \\
\hline Vývěry Punkvy & 2 & 240 & 2008 & 54 & - & - & - & 13 \\
\hline Habrůvecká bučina & 1 & 120 & 2008 & 36 & 3 & - & 12 & 18 \\
\hline Býčí skála & 1 & 120 & 2008 & 36 & 3 & - & 12 & 18 \\
\hline U Spálené & 1 & 300 & 2009 & 37 & - & 62 & - & 41 \\
\hline Dvorčák & 1 & 120 & 2009 & 47 & - & 33 & - & 28 \\
\hline Šargoun-Bahna & 1 & 350 & 2010 & 61 & - & - & - & 15 \\
\hline Litoměřice & 10 & 456 & 2009 & 36 & - & 36 & 24 & 39 \\
\hline Májová & 5 & 363 & 2008 & 88 & - & 15 & - & 30 \\
\hline Buchlovice & 8 & 487 & 2008 & 33 & 43 & - & - & 51 \\
\hline Zborovskýles & 3 & 90 & 2007 & 57 & - & - & - & 14 \\
\hline Total & 33 & 2,538 & & & & & & \\
\hline
\end{tabular}

* according to available data of the game management registration or according to information of state administration or a game manager; conversion to ungulate according to Notice No. 491/2002 Gaz., i.e. 1 pc of ungulate = 1 pc Cervus elaphus or 2 pcs Dama dama or 2 pcs Ovis musimon or 4 pcs Capreolus capreolus 


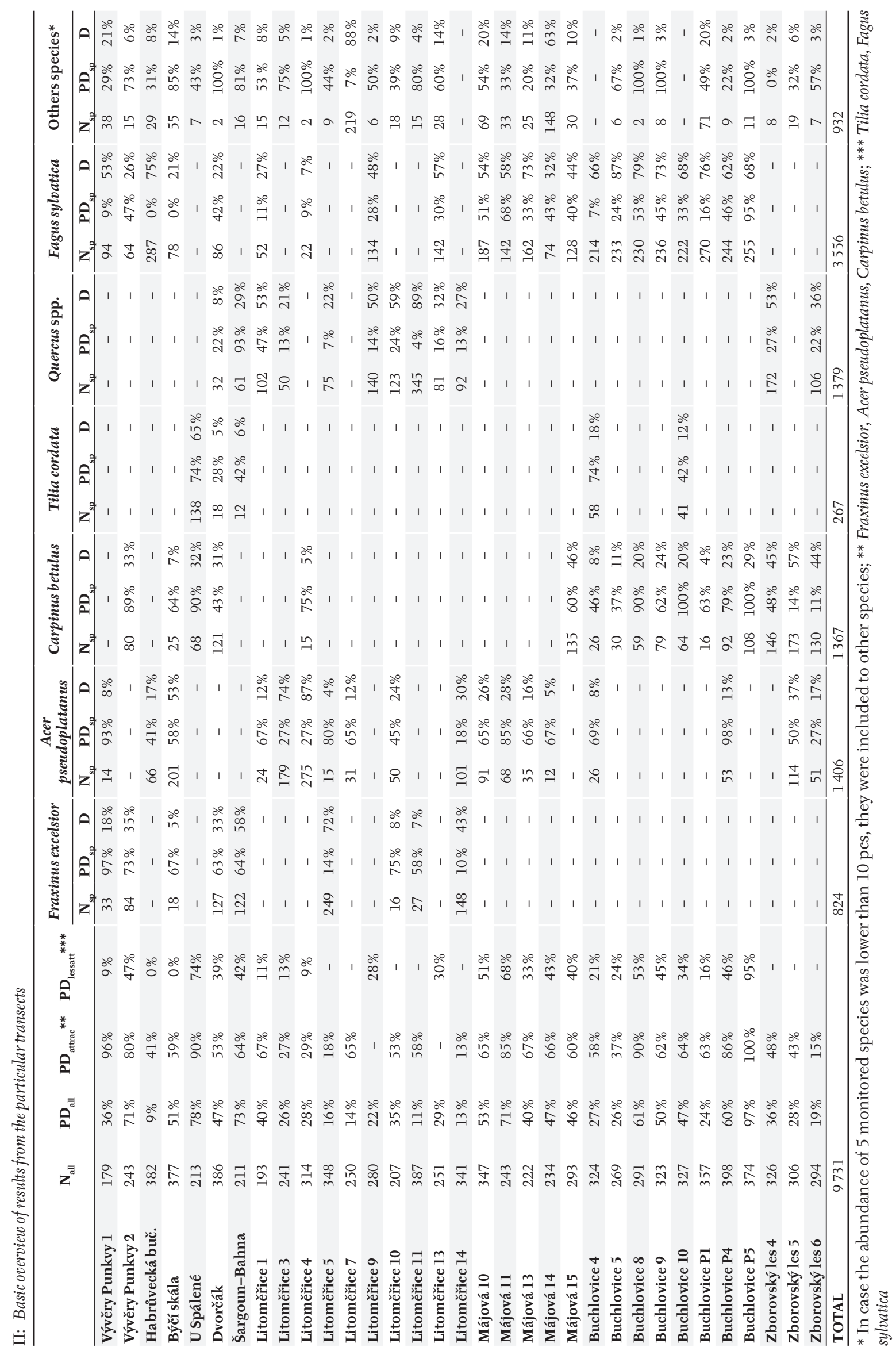


to Notice No. 491/2002 Gaz.) ranged from 13 to 51 individuals /1000 ha (see Table I.).

For each of 33 transects, following parameters were determined:

- number of individuals of a species (abundance) $\mathrm{N}_{\mathrm{sp}}$

- number of individuals of all species $-\mathrm{N}_{\text {all }}$;

- number of damaged individuals of a species $-\mathrm{N}_{\mathrm{dam}}$;

- number of damaged individuals of all species $\mathrm{N}_{\mathrm{dam} \text { all }}$;

- damage to a species in \% - $\mathrm{PD}_{\mathrm{sp}}=\left(\mathrm{N}_{\mathrm{dam}} / \mathrm{N}_{\mathrm{sp}}\right) \times 100$;

- damage to all species in \% - $\mathrm{PD}_{\text {all }}=\left(\mathrm{N}_{\mathrm{dam} \text { all }} / \mathrm{N}_{\text {all }}\right)$ $\times 100$;

- dominance $-\mathrm{D}=\left(\mathrm{N}_{\mathrm{sp}} / \mathrm{N}_{\mathrm{all}}\right)$ * 100;

- a difference between damage to a species and damage to all species DifPD $=\mathrm{PD}_{\mathrm{sp}}-\mathrm{PD}_{\text {all }}$.

- the proportion of damage to a species and damage to all species $\mathrm{RPD}=\mathrm{PD}_{\mathrm{sp}} / \mathrm{PD}_{\text {all }}$.

The data were processed using correlation and regression analysis. The calculation of correlation coefficients of linear correlations and testing their significance by Student t-test was carried out in Excel as well as polynomial regression. Correlations were determined for particular tree species and for three aggregate groups of species.

After the first correlation and regression analysis the highly food-attractive species and the less foodattractive species were defined (in detail in Results) and following parameters were determined:

- number of individuals of highly food-attractive species (A.p. +C.b. F.e.) $-\mathrm{N}_{\text {attrac }}$;

- number of individuals of less food-attractive spe$\operatorname{cies}($ F. s. + T. . . $)-\mathrm{N}_{\text {lessatt }}$;

- number of damaged individuals of highly food-attractive species (A.p. + C. b. + F.e.) $-\mathrm{N}_{\mathrm{dam} \text { attrac. }}$;

- number of damaged individuals of less food-attractive species (F.s., T. c.) $-\mathrm{N}_{\text {dam lessatt. }}$;

- damage to highly food-attractive species in \% $\mathrm{PD}_{\text {attrac }}=\left(\mathrm{N}_{\text {dam attrac }} / \mathrm{N}_{\text {attrac }}\right) \times 100$;

- damage to less food-attractive species in $\%-\mathrm{PD}_{\text {lessatt }}$ $=\left(\mathrm{N}_{\text {dam lessatt }} / \mathrm{N}_{\text {lessatt }}\right) \times 100$;

- dominance of highly food-attractive species $-\mathrm{D}_{\text {at- }}$ trac $=\left(\mathrm{N}_{\text {attrac }} / \mathrm{N}_{\mathrm{all}}\right) \times 100$;
- dominance of less food-attractive species $-\mathrm{D}_{\text {lessatt }}=$ $\left(\mathrm{N}_{\text {lessatt }} / \mathrm{N}_{\text {all }}\right) \times 100$;

- a difference between damage to highly food-attractive species and damage to all species DifPD $_{\text {attrac }}=$ $\mathrm{PD}_{\text {attrac }}-\mathrm{PD}_{\text {all }}$;

- a difference between damage to less food-attractive species and damage to all species DifPD $D_{\text {lessatt }}=$ $\mathrm{PD}_{\text {lessatt }}-\mathrm{PD}_{\text {all }}$;

- the proportion of damage to highly food-attractive species and damage to all species $\mathrm{RPD}_{\text {attrac }}=$ $\mathrm{PD}_{\text {attrac }} / \mathrm{PD}_{\text {all }}$;

- the proportion of damage to less food-attractive species and damage to all species $\mathrm{RPD}_{\text {lessatt }}=$ $\mathrm{PD}_{\text {lessatt }} / \mathrm{PD}_{\text {all }}$.

\section{RESULTS AND DISCUSSION}

The total overview of results is given in Table II, results of correlation analysis and testing the significance of correlation coefficients in Tables III and IV and in Fig. 1. At three species of trees, viz. Acer pseudoplatanus, Carpinus betulus and Fraxinus excelsior, a negative correlation coefficient was found between the per cent of browsing of damaged individuals $\left(\mathrm{PD}_{\mathrm{sp}}\right)$ and abundance $\left(\mathrm{N}_{\mathrm{sp}}\right)$ and negative correlations between all three parameters expressing the rate of damage $\left(\mathrm{PD}_{\mathrm{sp}}\right.$, DifPD, RPD) and dominance (D) (see Table III, Fig. 1). It applies also for the set of data of all three species. For Acer pseudoplatanus and the set of data of all three species, all three correlations mentioned above are significant. At Carpinus betulus, following correlations are significant: the difference of damage to hornbeam and all tree species (DifPD) with dominance (D), the proportion of damage to hornbeam and all tree species (RPD) with dominance. At Fraxinus excelsior, following correlations are significant: percentage damage ( $\mathrm{PD}_{\mathrm{sp}}$ ) with abundance $\left(\mathrm{N}_{\mathrm{sp}}\right)$, the difference of damage to ash and all tree species (DifPD) with dominance (D).

The determined correlations prove an assumption that all three species rank among highly foodattractive species and their relative rate of damage increases with their decreasing abundance or dominance. Lower correlation coefficients for $\mathrm{PD}_{\mathrm{sp}}$ at

III: Correlation coefficients and their significance for all tree species

\begin{tabular}{|c|c|c|c|c|c|}
\hline \multirow[b]{2}{*}{$\begin{array}{l}\text { Tree species (group } \\
\text { of species) }\end{array}$} & \multirow[b]{2}{*}{$\begin{array}{c}\text { Number of } \\
\text { transects (items) }\end{array}$} & \multirow{2}{*}{$\begin{array}{c}\text { Correlation } \\
\text { coefficient - } \\
\text { correlation } \\
\text { of } \mathbf{N}_{\mathrm{sp}} \text { with } \mathrm{PD}_{\mathrm{sp}}\end{array}$} & \multicolumn{3}{|c|}{ Correlation coefficient $r$ - correlation of $D$ with } \\
\hline & & & $\begin{array}{c}\text { PD } \\
\text { (\% of damaged) }\end{array}$ & $\begin{array}{c}\text { DifPD } \\
\text { (differences } \\
\mathbf{P D}_{\mathrm{sp}} \text { and } \mathbf{P D}_{\text {all }} \text { ) }\end{array}$ & $\begin{array}{c}\text { RPD (rate of } \\
\text { PD }_{\text {sp }} \text { and } \text { PD }_{\text {all }} \text { ) }\end{array}$ \\
\hline Acerpseudoplatanus & 18 & $-0.552 * *$ & $-0.579 * *$ & $-0.698^{* * *}$ & $-0.489 *$ \\
\hline Carpinus betulus & 17 & -0.372 & -0.350 & $-0.654 * * *$ & $-0.736^{* * *}$ \\
\hline Fraxinus excelsior & 9 & $-0.769 * *$ & -0.609 & $-0.752 * *$ & -0.615 \\
\hline $\begin{array}{l}\text { Set of three species - } \\
\text { A. p. + C. b. + F. e. }\end{array}$ & 44 & $-0.538 * * *$ & $-0.518 * * *$ & $-0.699 * * *$ & $-0.549 * * *$ \\
\hline Quercus sp. & 12 & -0.303 & -0.122 & 0.150 & -0.070 \\
\hline Tilia cordata & 5 & 0.790 & 0.730 & 0.168 & 0.068 \\
\hline Fagus sylvatica & 22 & 0.207 & 0.188 & $0.459 *$ & 0.251 \\
\hline
\end{tabular}

* coefficient is significant at $\alpha=0.04 ;{ }^{* *}$ coefficient is significant at $\alpha=0.02 ;{ }^{* * *}$ coefficient is significant at $\alpha=0.01$ 

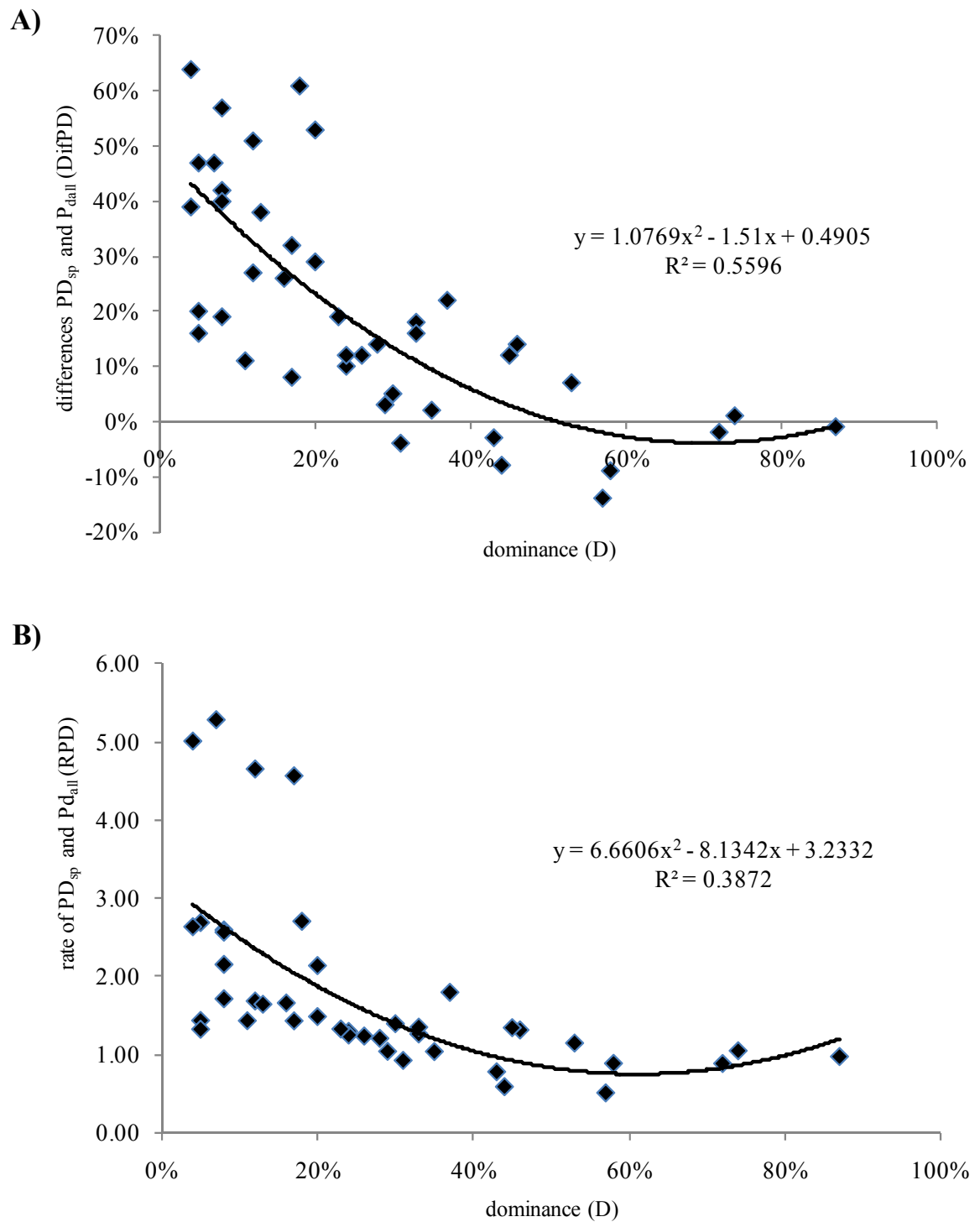

1: Polynomial regression of a species dominance (D) with A) a difference between damage to a species and damage to all species (DifPD) and B) a proportion of damage to a species and damage to all species (RPD) - set of three species (A.p. + C. b. + F. e.)

Carpinus betulus (Tab. III) are caused by several plots at the Buchlovice locality where hornbeam showed relatively high abundance and, at the same time, it was heavily damaged. Generally, these plots were heavily damaged by browsing $\left(\mathrm{PD}_{\text {all }}\right)$. If the rate of damage to hornbeam is expressed in relation to damage to all species (DifPD, RPD), correlation coefficients are logically higher than for $\mathrm{PD}_{\mathrm{sp}}$ and exceed levels of significance.

Statistically significant negative correlations between dominance (or relative abundance of a species expressed otherwise) and the intensity of damage were found in natural regeneration at Carpinus betulus (ČERMÁK, 1998), Acer pseudoplatanus, Acer platanoides, Sorbus aucuparia (ČERMÁK et al., 2009) or at Pinus sylvestris and Populus tremula (PADAIGA, 1986). Higher damage to less occurring species was walso noted by PAULENKA (1986), HORVAT (1990), AMMER (1996), SENN, SUTER (2003) or STERGAR
(2005). Relationships between the species proportion and damage were not statistically evaluated and tested in detail in these studies.

At oak Quercus spp., there was no evident relationship between browsing damage and the proportion of oak on studied plots. Only very low correlation relationships were determined, three out of four relationships given in Tab. III being negative and one positive. The rate of damage was evidently determined by other factors, e.g. by the growth of trees (biomass, noticeable shoots in the herb layer), distribution of trees etc.

At remaining species, viz. Tilia cordata and Fagus sylvatica, all four correlation relationships were positive (Tab. III). However, the only of the correlation relationships was statistically significant, namely, a relationship between the difference of damage to Fagus sylvatica and all species (DifPD) and the dominance of beech (D). Both species can be specified as 
IV: Relationships between less food-attractive species (Fagus sylvatica, Tilia cordata) and highly food-attractive species (Acer pseudoplatanus, Fraxinus excelsior, Carpinus betulus) - correlation coefficients and their significance

\begin{tabular}{|c|c|c|c|}
\hline \multirow{2}{*}{ Group of species/Parameter } & \multirow{2}{*}{ Number of transect } & \multicolumn{2}{|c|}{$\begin{array}{l}\text { Correlation coefficient } r \text { - correlation of the } \\
\text { parameter with }\end{array}$} \\
\hline & & $\begin{array}{l}\text { Dominance of highly } \\
\text { food-attractive species }\end{array}$ & $\begin{array}{l}\text { Dominance of less } \\
\text { food-attractive species }\end{array}$ \\
\hline Less food-attractive species & 23 & & \\
\hline $\mathbf{P D}_{\text {lessatt }}(\%$ of damaged) & & -0.118 & 0.212 \\
\hline DifPD $_{\text {lessatt }}$ (differences $\mathbf{P D}_{\text {lessatt }}$ and $\mathbf{P D}$ all $)$ & & $-0.453 * *$ & $0.603 * * *$ \\
\hline $\mathbf{R} \mathbf{P D _ { \text { lessatt } }}\left(\right.$ rate of $\mathbf{P} \mathbf{D}_{\text {lessatt }}$ and $\left.\mathbf{P D _ { \text { all } }}\right)$ & & -0.330 & 0.395 \\
\hline High food-attractive species & $31(23 *)$ & & \\
\hline $\mathrm{PD}_{\text {attrac }}$ (\% of damaged) & & $-0.500 * * *$ & 0.256 \\
\hline DifPD $_{\text {attrac }}$ (differences $\mathbf{P D}_{\text {attrac }}$ and $\mathbf{P D _ { \text { all } }}$ ) & & $-0.655^{* * *}$ & $0.494 * * *$ \\
\hline $\mathbf{R P D}_{\text {attrac }}\left(\right.$ rate of $\mathbf{P D}_{\text {attrac }}$ and $\left.\mathbf{P D}_{\text {all }}\right)$ & & $-0.498 * * *$ & $0.408 * *$ \\
\hline
\end{tabular}

* number of transect for correlation of the parameter with dominance of less food-attractive species

less food-attractive with respect to the positive value of correlation coefficients. Their damage increases particularly where they reach high relative abundance, i.e. where game is not in a position to consume the sufficient amount of another markedly more attractive tree species.

In the second stage of our analysis, correlation and regression analyses were carried out for two groups of trees: highly food-attractive (Acer pseudoplatanus, Carpinus betulus, Fraxinus excelsior) and less food-attractive (Fagus sylvatica, Tilia cordata), see Table IV. Statistically significant negative correlations were found (as expected) between damage to highly foodattractive species $\left(\mathrm{PD}_{\text {attrac }}\right.$, DifPD $\left.\mathrm{D}_{\text {attrac }}, \mathrm{RPD}_{\text {attrac }}\right)$ and dominance of these species ( $\mathrm{D}_{\text {attrac }}$ ). For DifPD and $\mathrm{RPD}_{\text {attract }}$, also statistically significant positive correlations were determined with dominance of less food-attractive species $\left(\mathrm{D}_{\text {lessatt }}\right)$, see Table IV. Thus, the higher the percentage proportion of highly food-attractive species and the lower the proportion of less food-attractive species then the lower the relative intensity of damage to highly food-attractive species. The statistically significant positive correlation between damage to highly food-attractive species (DifPD attrac, $\mathrm{RPD}_{\text {attrac }}$ ) and the dominance of less food-attractive Fagus sylvatica was already detected for the previous series of plots (ČERMÁK et al., 2009).

Moreover, significant positive correlations were found between the difference of damage to lessattractive species and all species $\left(\operatorname{DifPD}_{\text {lessatt }}\right)$ and dominance of these species $\left(\mathrm{D}_{\text {lessatt }}\right)$. Significant negative correlation was determined between DifPD ${ }_{\text {lessat }}$ and dominance of highly food-attractive species $\left(D_{\text {attrac }}\right)$, see Table IV. Thus, the higher the percentage proportion of highly food-attractive species and the lower the proportion of less food-attractive species then the lower a difference between damage to less food-attractive species and all species. Effects of the abundance of highly food-attractive species on damage to less food-attractive Fagus sylvatica were also monitored by EIBERLE, BUCHER (1989) in the Bern canton. These authors found that the higher dominance of Acer pseudoplatanus, Fraxinus excelsior and Sorbus aucuparia lowered damage to Fagus sylvatica. Slight damage to beech at heavy damage to other species (highly food-attractive) was also found at research carried out in Gorczanski Park Narodowy in Poland (MISCICKI, ZUREK, 1995) or in the surroundings of Brno (MODRÝ et al., 2004).

Similarly as in case of the previous study (ČERMÁK et al., 2009), we consider that it is suitable to use particularly both parameters expressing damage to a species in relation to damage to all species (i.e. DifPD and RPD) to evaluate relationships between the intensity of damage and dominance. Particular plots of our surveys showed rather balanced total abundance of trees, viz. from 179 to 398 trees. However, they differed diametrically in the total percentage of trees damaged by browsing ( $\left.\mathrm{PD}_{\text {all }}\right)$ - from 9\% (Habrůvecká bučina) to 97\% (Buchlovice $\mathrm{P} 5)$. Thus, the same percentage of damage to a given species $\left(\mathrm{PD}_{\mathrm{sp}}\right)$ is relatively high at a plot with respect to the total damage, at another plot, however, relatively low and this relativity is not taken into account at the correlation of abundance $\left(\mathrm{N}_{\mathrm{sp}}\right)$ or dominance (D) with $\mathrm{PD}_{\text {sp. }}$ Considerable differences in the intensity of damage can be always expected when it concerns plots from different localities or from one locality but rather large or various. In addition to the abundance of game, intensity of damage can be affected by a number of other factors (e.g. proximity of a feed trough, roads, possibilities of a shelter for game, the presence and amount of other food sources, particularly Rubus spp.). Results of a regression analysis (Fig. 1) show that relationships of both relative parameters (DifPD, RPD) with dominance are of a polynomial character. With respect to the nature of these parameters the course of curves is obvious, namely with the increasing dominance effects of a species on the total damage also increases $\left(\mathrm{PD}_{\text {all }}\right)$. At high dominances, a difference and the proportion of damage to a species and damage to all species are, therefore, close to zero or close to one. 


\section{SUMMARY}

The aim of the paper was to analyse relationships between the intensity of browsing damage and dominance at three tree species, which were analysed in the past (ČERMÁK et al., 2009) - Acer pseudoplatanus, Fraxinus excelsior, Fagus sylvatica and three other species. One of these species is considered to be food-attractive, namely Carpinus betulus and at two of them, the rate of attractiveness is not unambiguous, viz. Quercus spp. and Tilia cordata. Field survey was carried out in 2007-2010. Analysed data come from 33 transects at 10 localities with the various abundance of game in the CR (Capreolus capreolus, at some plots also Cervus elaphus, Ovis musimon or Dama dama). Trees in natural regeneration under a stand as well as in planted plantations were monitored up to a height of $150 \mathrm{~cm}$ and the occurrence was noted of new browsing damage. At three tree species, namely Acerpseudoplatanus, Carpinus betulus and Fraxinus excelsior, a negative correlation relationship was detected between the per cent of damaged trees $\left(\mathrm{PD}_{\mathrm{sp}}\right)$ and abundance $\left(\mathrm{N}_{\mathrm{sp}}\right)$ and negative correlations between all three parameters expressing the rate of damage ( $\mathrm{PD}_{\mathrm{sp}}$, DifPD, RPD) and dominance (D). In the majority of cases, it referred to correlations with the high level of significance. The correlations confirm a hypothesis that all three species rank among highly food-attractive species and their relative rate of damage increases with their decreasing abundance or dominance. At Quercus spp., there was no relationship between browsing damage and the proportion of oak. Only very weak correlation relationships were detected. At remaining two species, viz. Tilia cordata and Fagus sylvatica, all four correlation relationships were positive (Tab. III). Only one of them was statistically significant, namely a relationship between the difference of damage to Fagus sylvatica and to all species (DifPD) and the dominance of beech (D). With respect to the positive value of correlation coefficients, both species can be considered to be less foodattractive. Their damage increases particularly where they reach high relative abundance, i.e. where game is not able to consume other markedly more food-attractive species in sufficient amount. With respect to high differences in the total browsing damage $\left(\mathrm{PD}_{\text {all }}\right)$ at particular plots we consider to be suitable to use particularly both parameters (i.e. DifPD and RPD) expressing damage to a species in relation to damage to all species to evaluate relationships between the intensity of damage and dominance.

\section{Acknowledgement}

The paper was supported by the MSMT project No. 6215648902 "Forest and Wood".

\section{REFERENCES}

AMMER, CH., 1996: Impact of ungulates on structure and dynamics of natural regeneration of mixed mountain forests in the Bavarian Alps. Forest Ecology and Management, 88: 45-53. ISSN 03781127.

ČERMÁK, P., 1998: Vliv sudokopytníků na lesní ekosystémy Moravy. Lesnictví - Forestry, 44: 278-287. ISSN 1212-4834.

ČERMÁK, P., 2000: Vliv sudokopytníků na dřeviny vybraných lesních ekosystémů. Disertační práce FLD MZLU Brno, 157 pp.

ČERMÁK, P. HORSÁK, P., ŠPIŘÍK M., MRKVA, R., 2009: Relationships between browsing damage and woody species dominance. Journal of Forest Science, 55, 1: 23-31. ISSN 1212-4834.

DANELL K., EDENIUS L., LUNDBERG P., 1991: Herbivory and tree stand composition: moose patch use in winter. Ecology, 72: 1350-1357. ISSN 0012-9658.

EIBERLE, K., BUCHER, H., 1989: Interdependenzen zwischen dem Verbiss verschiedener Baumarten in einem Plenterwaldgebiet. Zeitschrift für Jagdwissenschaft, 35: 235-244. ISSN 0044-2887.
GARTNER, S., 1996: Welches heimische Laubholz wird bevorzugt verbissen? AFZ Der Wald, Allgemeine Forst Zeitschrift für Waldwirtschaft und Umweltvorsorge, 51, 18: 1009-1010. ISSN 1430-2713.

HEROLDOVÁ, M., 1997: Trophic niches of three ungulate species in the Pálava Biosphere Reserve. Acta Scientarium Naturalium Academiae Scientiarum Bohemicae Brno, XXXI Nova Series 1997, 52 pp. ISSN 0032-8758.

HOLIŠOVÁ, V., OBRTEL, R., KOŽENÁ, I., 1986: Seasonal variation in the diet of field roe deer (Capreolus capreolus) in Southern Moravia. Folia Zoologica, 35, 2: 97-115. ISSN 0139-7893.

HORVAT, T., 1990: Prehranska ekologia rastlinojede divjadi kot element sanacije razpadajočich jelovobukovih gozdov v spodnjem montanskem pasu. Diplomsko delo BF-UL v Ljubljani, 80 pp.

KAY, S., 1993: Factors affecting severity of deer browsing damage within coppiced woodlands in the south of England. Biological Conservation, 63, 3: 217-222. ISSN 0006-3207.

KULLBERG, Y., BERGSTRÖM, R., 2001: Winter browsing by large herbivores on planted deciduous seedlings in southern Sweden. Scandinavian 
Journal of Forest Research, 16, 4: 371-378. ISSN 02827581.

MISCICKI, S., ZUREK, Z., 1995: Inwentaryzacja odnowienia lasu i jego uszkodzen przez jeleniowate w gorczanskim parku narodowym. Sylwan, 139, 10: 53-69. ISSN 0039-7660.

MODRÝ, M., HUBENÝ, D., REJŠEK, K., 2004: Differential response of naturally regenerated European shade tolerant tree species to soil type and light availability. Forest Ecology and Management, 188 (1-3): 185-195. ISSN 0378-1127.

PADAIGA, V., 1986: Measures for protecting forest stands from elk damage. Metsanduslikud Uurimused, 21: 26-37. ISSN 1406-9954.
PAULENKA, J., 1986: Vplyv pol'ovnej zveri na odolnostný potenciál mladých lesných porastov. Folia Venatoria, 16: 31-50.

SENN, J., SUTER, W., 2003: Ungulate browsing on silver fir (Abies alba) in the Swiss Alps: belief in search of supporting data. Forest Ecology and Management, 95: 151-164. ISSN 0378-1127.

STERGAR, M., 2005: Objedenost mladja drevesnih vrst v odvisnosti od zgradbe sestoja. Diplomsko delo BF-UL v Ljublajana, 70 pp.

STROLE, T. A., ANDERSON, R. C., 1999: Whitetailed deer browsing: species preferences and implications for central Illinois forests. NCASI Technical Bulletin, 781: 520-521.

Address

doc. Ing. Petr Čermák, Ph.D., Bc. Pavla Beranová, Ing. Jindřiška Orálková, Ing. Petr Horsák, Ing. Jaroslav Plšek, Ústav ochrany lesů a myslivosti, Mendelova univerzita v Brně, Zemědělská 3, 61300 Brno, Česká republika, e-mail: cermacek@mendelu.cz 